\title{
Rune Stones as Material Relations in Late Pagan and Early Christian South Scandinavia
}

\author{
Julie Lund ${ }^{1}$ \\ ${ }^{1}$ Department of Archaeology, Conservation and History, University of Oslo, Norway (julie.lund@iakh.uio.no)
}

\begin{abstract}
In this article, the material qualities and the use of space on rune stone and its links to the landscape during the Viking Age and in the Early Medieval Period in South Scandinavia are explored and related to acts of commemoration and changing spatial perceptions. The $11^{\text {th }}$ century rune stones from Denmark and Scania without iconography have previously received less scholarly attention by the archaeologists, but here they form the main focus. Whereas the commemorative aspects of the rune stones have been noticed by a number of scholars, less emphasis has been on their material qualities and the spatial aspects of the inscription on the stones; the spatial references in the rune stones to the surrounding landscape; and the bodily effect they had for the readers of the runes. The rune stones are studied as expressions of social relations between living, deceased and places in late pagan and early Christian Scandinavia. Three phenomena are explored: the rune stones at bridges and the role of the bridge in paganism and Christianity; the use of the surface and shape of the stones to separate diverging beings; and the shape of the inscription and its relation to the new concepts of afterworld in terms of heaven above, while simultaneously creating links to near and distant pasts. Further, the process of creating relations to distant pasts in the Early Christian period is explored.
\end{abstract}

\author{
ARTICLE HISTORY \\ Received 20 No- \\ vember 2019; \\ Accepted 15 April 2020 \\ KEYWORDS \\ Rune stones;Viking \\ Age; Materiality; \\ Landscape; Early \\ Christianity.
}

\section{Introduction}

In this article, the use of space on the rune stone from the late Viking Age and Early Medieval Denmark and its links to the landscape will be explored. Raising the stones were acts of commemoration. The way in which the inscriptions cover the surface of the stones may provide us with insights into the principles of categorisation, as will be structinised in the following. As the inscription typically include the name of a deceased and the raiser of the rune stone, the manners in which living and deceased were categorised and located spatially may be studied through the inscription. Thus, various traditions in the way the rune stones were inscribed may be identified in pre- and post-conversion times. The physical engagement with the rune stones and their spatial setting in relation to the process of conversion in Scandinavia will be examined, focusing on the acts of commemoration and changing spatial perceptions during the conversion, as expressed in the use of the body of the stones and human bodies. Furthermore, as the Viking Age was a period in Scandinavian history in which the past was actively used and reworked in material terms (Andrén 2013; Artelius 2004; Arwill-Nordbladh 2008; Hållans Stenholm 2006; Lund and Arwill-Nordbladh 2016; Pedersen 2006), the raising of rune stones was one of the central means to express a close relationship to the deceased, whilst at the same time creating links to recent as well as distant pasts.

More than 3000 rune stones have been documented as raised in Scandinavia in this period. The majority were raised in the $10^{\text {th }}$ and $11^{\text {th }}$ century with the lion's share in Uppland, Sweden (Sawyer 2000, 7-12). In the rune stone tradition in present day Denmark and Scania, Sweden peaks slightly earlier (for a discussion of the chronology of the Danish rune stones, see Imer 2014, Stoklund 1991, 2006). The rune stones from this area are predominantly dated to the $9^{\text {th }}-11^{\text {th }}$ century, and more than 100 of these rune stones were raised in the time shortly 
after the conversion (Imer 2014, 171). This article will focus on the rune stones dated from ca. 900-1020/1025 AD; the Pre- and Post-conversion group in Lisbeth Imer's chronological study (Imer 2014). It will also include examples from the Bornholm group, which is slightly later, dating from ca. 1025-1125 AD, but which paralleled to the Post-conversion group of present-day Denmark and Scania. They represent the earliest Christian rune stones in the area in which they were raised; the island of Bornholm (Imer 2014). The aim of this focus is to single out some the principles of categorisation of beings, including living and deceased, and their spatial positions around the time of Conversion.

The Danish and Scanian rune stones have been used in studies of religion, focusing for example on the use of masks in the iconography or the concept of the pulr (presumably a skald or a reciter) (Imer 2016, 242). Other areas of interest concern political history, focusing on e.g. the control of land, or the social organisation e.g. military titles such as drengr (Enoksen 1999; Fuglesang 1981, 2005; Krogh 1982; Randsborg 1980; Sawyer 2008; Sawyer, Sawyer et al. 1987; Stoklund 1991; Sundqvist 2008). Possibly due to their elaborate iconography, the $11^{\text {th }}$ and $12^{\text {th }}$ century Christian rune stones of Södermanland and Uppland have been studied intensively (see for instance Andrén 2000; Back Danielsson 2015a, 2015b; Gräslund 2002, 2003; Gräslund and Lager 2008; Klos 2009; Lager 2003; Ljung 2016 with references). Similarly, a small group of decorated $11^{\text {th }}$ century rune stones from Hadeland in Norway, most significantly the rune stone from Dynna, has been utilised in analyses of early Christianity in Scandinavia (Fuglesang 1980; Jesch 1991; Staecker 2004; Steinsland 2014; Strömbäck 1970). In comparison, the early Christian $11^{\text {th }}$ century rune stones from present day Denmark and Scania in Sweden are among the least studied rune stones. A feasible reason is the lack of iconography on this group of stones, as consequently they can neither be used in analyses of the Viking Age society per se, nor as examples of early Christian art. This body of material has the potential to shed light on central aspects of the way humans interacted physically with the stones and used the materiality of the stones to find new ways of understanding and expressing the social relations between the living and the deceased in the time of the conversion to Christianity. In a qualitative analysis, it is the qualities and characteristics of a phenomenon which are being explored, not its quantitative expression. Such an approach is compulsory due to the more or less accidental selection of rune stones; namely the ones preserved or rediscovered and available in the present day. Furthermore, the total number of rune stones from Denmark and Scania is insufficient for statistically significant quantitative analysis. As the true size of the population of rune stone is unknown, this body of preserved material cannot be assumed to be a statistically representative sample. This does not render the material invalid for research, more that it requires a nuanced, qualitative approach that respects the social changes the material potentially represents within the discreet categories. Thus, this is not an exhaustive analysis of all South Scandinavian rune stones, but the identification of a number of phenomena within the group of Preand Post-conversion rune stones which may have wider implications for the comprehension of how these rune stones worked as acts of commemoration.

\section{Stones for Commemoration}

That objects and structures may have greater endurance than human beings provide them with the potential to work as parts of commemorative processes. Roberta Gilchrist states that heirlooms are repositories for collective memory (Gilchrist 2013, 170). Portable artefacts are not alone in this capacity; monuments and other objects which did not circulate physically have this ability. Rune stones are created as places of commemoration, most often to the deceased, but they have also had additional social functions. They are examples of the strong focus in the Viking Age on relating to and revitalising the past (Ljung 2016, 49-53). Whereas Birgit Sawyer has interpreted the rune stones as avowals of property and inheritance (Sawyer 1988), Torun Zachrisson has seen them as memorial inscriptions which were additionally, albeit more indirectly, used as protectors of the property, as the raiser demonstrated their relations whilst si- 
multaneously placing the deceased in their social network (Zachrisson 1994, 233). These perspectives are rewarding, as they point to the relational aspects of the inscription. Thus, the rune stones may essentially be understood as expressions of $s o-$ cial relations between the living, the deceased, and places in late pagan and early Christian Scandinavia (see also Imer 2016, 68).

The process of remembering, which takes place through the memory of former action, is always something on its own terms; a transformation of the tradition (Gadamer 2001 [1960], 131). Essentially, in the process of remembering, there is always a link to a new memory (Olick 1999, 340). Material culture, and in particular monuments, may function as mnemonic agents for the collective memory of social groups (Assmann 1995; Bradley 1993; Halbwachs 1992; Thomas 1996; van Dyke and Alcock 2003; Williams 1998). The human experience with the landscape is a bodily experience. Moreover, material culture embodies particular elements in the landscape. In these processes, it is material culture which brings memory into a place (Harris 2010; Ingold 1993, 152-154; Jones 1998, 302, 2007; Lund 2009, 103-110; Lund and Arwill-Nordbladh 2016). In recent years, a focus on materiality has caused an increased awareness on the interplay between objects and humans, on the qualities of material objects, and on the effects and affects of materiality on humans, and in particular the human body (Gosden 2005; Harris 2010; 2016, Malafouris 2013; Pétursdóttir 2012, Tarlow 2012). In essence, humans encounter the world through our bodily experience with the world, and the sensorial is not separated from the perceptional in this meeting (Merleau-Ponty 1994, 11-12). As Yannis Hamilakis points out, memory is activated through the sensorial interaction with matter (Hamilakis 2013, 118-124). On a universal level, memory is fundamentally linked to place. Neuro-scientific research demonstrates that all memories are bound to places, as memory and reference of place is stored as a unit in the human brain (Moser and Moser 1998, Moser 2005). This means that in order to learn where places are located in space, one has to associate the places with specific events. Thus, the material dimensions of memory also include aspects of spatiality. Stefan Brink has pointed out that particularly in societies where writing was not yet well established, the landscape could function as the container and conserver of cultural memory (Brink 2008, 119). It may, however, be rewarding to take this a step further by acknowledging that the landscape was not merely a container, but acted back on the human agents living in and of the landscape. Raising rune stones were part of changing the places in a process of place-making. The commemorative aspects of the rune stones have been noticed by a number of scholars (Gräslund 2002; Ljung 2016; Sawyer 2000). Ing-Marie Back Danielsson has reflected on spatial aspects and the physical engagement with rune stones through an analysis of a number of Christian rune stones from the Mälar valley with elaborate iconography (Back Danielsson 2015b). Even the South Scandinavian rune stones, which lack this type of highly detailed iconography, hold the potential for analysing the spatial aspects of the inscription on the stones and the spatial references in the rune stones to the surrounding landscape. In the following, these spatial aspects and the bodily effect they had for the readers of the runes will be examined.

The inscriptions as well as the locations of the rune stones indicate that there was a profound, deep felt need to create memory in Viking Age Scandinavia (Lund and Arwill-Nordbladh 2016; Williams 2016). The stones are often located in relation to cemeteries (Back Danielsson 2015a, 162-164; Larsson 1990, 162). Several inscriptions state that they were raised with the purpose of commemorating the deceased and remember the raiser of the stone. The acts of raising the rune stones were commemorations of social relations; in particular social relations between the living bereaved and the deceased. In this expression, it is central to underline their physicality. Interpretations of prehistoric standing stones point towards the importance of the materiality of the stones (see for instance Kohring 2014; Robb 2009). This is even relevant for the rune stones and includes placing emphasis on the material qualities of the raised stones (see Back Danielsson 2015a, 158 with references). These important notions remind us that the rune stones did not simply represent relations. They materialised them. Where the physical body 
of the deceased was decaying in the soil, the body of the rune stone was present in the landscape as a real and substantial entity. Thus, rune stones may have been raised to create memory, but their outcome was far wider, as they were not merely mental ideas, but material objects which affected the humans that engaged with them. The effect of the rune stone must have varied depending on whether or not the observer or reader of the rune stone was literate or illiterate, as the process of reading the runes also included a bodily movement of the reader, depending on where on the stone the inscription was. This physical engagement with the rune stone further related to the location of the rune stone in the landscape, as will be demonstrated in the following.

\section{The Use of Space in the Composition of the Runic Inscriptions}

The Scandinavian rune stones have mainly been analysed by philologists, art historians, and archaeologists, focusing respectively on the texts, the images on the stones, and their location in the landscape. In a methodologically innovative article from 2000, Anders Andrén points out the shortcomings of this labour division, as a large number of the rune stones were clearly produced with the ambition of a combined reading of the stones (2000). Several of the stones contain references to kjenninger, pre-set metaphors used in the Skaldic poetry. A striking example is the Tumbo stone (Sö $82^{1}$ ) from Södermanland, Sweden, which contains an inscription stating that the stone is raised by 'Visten (...) after Frøsten, his brother, death/dead in Greece (...)'. The image on the stone shows a beast biting around the word 'death', which Andrén relates to the kjenning 'to become the wolf's food', known from the Skaldic poetry (Andrén 2000). Andrén's reinterpretation of this stone demonstrates that different social groups would have had divergent access to understanding and thus using the rune stone for commemoration, depending on not only whether or not the observer/ reader of the rune stone was illiterate or not, but also depending on the reader was familiar with Skaldic poetry used among the social elite (for a discussion on litteracy and rune stones in relation to the Swedish early medieval stones, see also Bianchi 2010).
Andrén's approach to interpreting the rune stones appears to be particular applicable to the Swedish Late Viking Age stones, as they very often include ornamentation and visual images. Yet, the approach is also relevant for analysing rune stones which do not contain visual images, as even the location and configuration of the inscription on the surface of the stone relate directly to concepts and metaphors used in Viking Age Scandinavia (Lund 2005, 2009, 134-148). As will be demonstrated in the following, the outline of the runic inscriptions on stones are formed and shaped in accordance with fundamental principles that relate directly to the world-views and mentalities of the Viking Age. These principles, which have been overlooked in previous research, include distinct means of separating living and deceased and between humans and other beings. The properties of the inscriptions shape the ways in which the stones, including its material qualities and characteristics in terms of shape and form, have been used.

\section{Dividing the Living and the Deceased}

A noticeable feature on the Pre- and Post-conversion rune stones is the composition of the inscription. The scheme ' $\mathrm{X}$ raised this stone after Y' dominates the material (Imer 2016, 135). A large proportion of the rune stones separate the name of the living and the name of the deceased on two separate bands. This pattern can be identified on 92 rune stones $(89.3 \%)$ of the Pre- and Post-conversion rune stones from present day Denmark and Gottorp County ${ }^{2}$ in Schleswig. The high percentage of occurrences of this pattern indicates that this inscription design was not accidental, although as pointed out in the introduction, the total number of raised stones is unknown. Simultaneously, this was clearly not an unalloyed pattern, but one of several in a repertoire of schemes. The same pattern can be identified in the group of Pre- and Post-conversion rune stones from Scania, Sweden, but appears to be less dominating, occurring on 47 (65.3\%) of rune stones in these groups. This lower occurrence is not surprising considering that the dates of the Scanian rune stones are, in general, some years younger than the Danish rune stones from eastern Jutland (Imer 
2014, 170-171). Moreover, as will be demonstrated later in this article, a new scheme emerges for the explicit Christian Post-Conversion rune stones, for which the traditional separation of being through bands gives way to new forms. The remaining 11 (10.6\%) of Pre- and Post-conversion rune stones from present-day Denmark also separate the name of the living and the deceased, not through two separated bands, but by letting the band of the inscription run in a spiral or portal in which the name of the living and the deceased are located the furthest away from each other. Similarly, most of the remaining 20 (42.6\%) Scanian rune stones of the Pre- and Post-conversion group do not separate the living and the deceased in two bands, but locate their names on either sides of a portal or a spiral. In addition, there are three of the Pre- and Post-conversion rune stones that fall completely outside of this pattern, as they are raised in memory of the raiser himself and thus naturally do not contain the same segregation of the deceased and the bereaved. A typical feature in the South Scandinavian rune stones of the Pre- and in particular Post-conversion group dating to c. 900-1020/1025 (Imer 2014, 170-174; Stoklund 1991, 191), is that Y's name is followed by some of the qualities or the title of $\mathrm{Y}$, such as 'Y, a very noble pegn' (Old Norse most presumably meaning magnate (Imer 2016, 25, for a discussion on the difficulties in seperating the Pre- and Post-conversion rune stones, see Imer 2014:168-171). These stones were raised in the period of transition from paganism to Christianity. Typically, the inscription also describes the relationship between the raiser and the deceased.
One noticeable conceptual way of separating living and deceased is the bridge. Viking Age South Scandinavian settlement and cemeteries were in many cases ${ }^{3}$ divided by a stream and connected by a bridge or a ford (Adamsen 2004; Lund 2005). This division arguably finds equivalence in a number of Old Norse written sources, pointing towards the conceptual idea of the realm of the living and the dead as being divided by a river or stream and connected by a bridge (Adamsen 2004; Hedeager 2002; Lund 2005, 2009, 127-147). During the Viking Age, artefacts - mainly weapons and tools - were laid down in the water in close proximity to bridges and fords as part of ritual or structured acts of deposition (Lund 2005, 2009, 127-139). Similarly, a number of silver hoards have been deposited in wetlands in liminal places including at bridges (Hedeager 2003; Zachrisson 1998, 114-117). In the same period and in the same regions, bridges and fords were being marked by the raising of rune stones (Enoksen 1999; Larsson 1990; Lund 2005; Thörn 2004; Øeby-Nielsen 2005).

The rune stones with the word bridge in the inscriptions from present-day Denmark are few, but most of them are early Christian stones (Imer 2016, 292). The inscriptions mentioning a bridge follow the scheme ' $\mathrm{X}$ raised this stone and built this bridge after Y' (Lund 2005; Sawyer 2000). Thus, the spatial concept of the bridge as a threshold connecting the living and the dead, who were located on each side or bank is expressed in the composition of the inscriptions. This metaphorical thinking is also conveyed in other manners. The Källstorp stone (DR 269) (Figure 1) has a Christian inscription, which follows the same principle
Figure 1. The Källstorp stone, Scania, Sweden (after Jacobsen and Moltke 1941, plate 645-646).
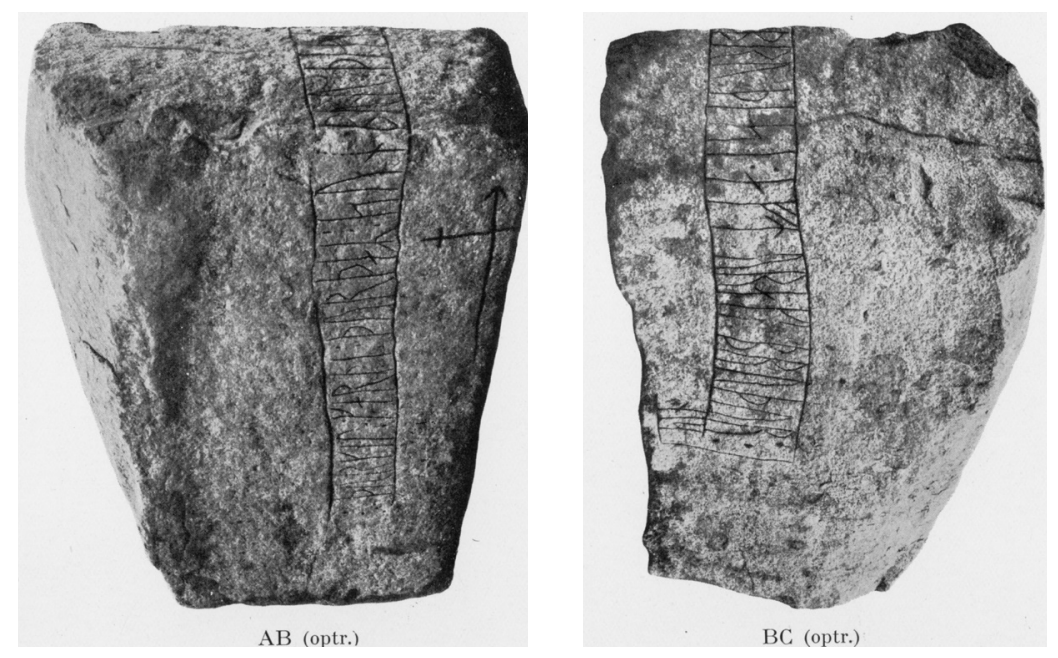
as the rune stones at bridges, yet with the inscription in one belt, with the word bridge written on the top of the ridge of the stone (Lund 2005). The stone is part of the Post-conversion group, dating it to c. 970-1020/1025 (Imer 2014, 170-173).

In other instances the inscription is divided in two opposite and parallel bands, one with the name of the raiser, and the other with the name of the deceased. The living and the dead were thereby separated, but also reflected on each side of the bands (Lund 2009, 137-142). A very direct expression of this is found on the Hjermind stone 2 (DR 78), where the first letter, Ty $(\uparrow)$, of the name of the raiser, Tove, is directly mirrored in the first letter, Ty $(\uparrow)$, of her son, Toste (Jacobsen and Moltke 1941, 76, 1942; Lund 2009, 139-140)(Figure 2). In our modern optic, the Tys even appear as arrows pointing towards each other, but as the arrow as a typographical symbol was developed in post-medieval times it was presumably not perceived similarly in the late Viking Age. Yet, optically the arrow shape of the Ty rune leads the eye towards the other Ty rune and mirrors it.

This spatial divisional principle is identifiable in rune stones with explicit pagan inscriptions as well as on unequivocal Christian examples. The ideas of the afterlife in Viking Age paganism appear to have been diverse and not mutually exclusive (Price 2008a, 2008b, 2014). Old Norse Scaldic poetry indicates that the grave itself could be considered a rest place for the deceased, at the same time as iconographic material of the period supports the identification of various otherworlds in the Old Norse written sources, including the idea of Valhall and $\mathrm{Hel}$ (see for instance Brink 2007; Lund 2013, with references for a discussion on the diverging ideas of afterlife in Viking Age Scandinavia; Steinsland 2005). The conversion to Christianity included an alteration in the role of the bridge in the cognitive landscape. In Early Medieval Christian Scandinavia of the $11^{\text {th }}$ century, it was no longer the body of the deceased that was thought to cross the bridge, but the soul. Bridge building was considered a good Christian deed equal to gifts to the church, not only for its practical function, but also for its role in the Christian perspective on the afterlife (Smestad 1988, 172; Thörn 2004, 245).

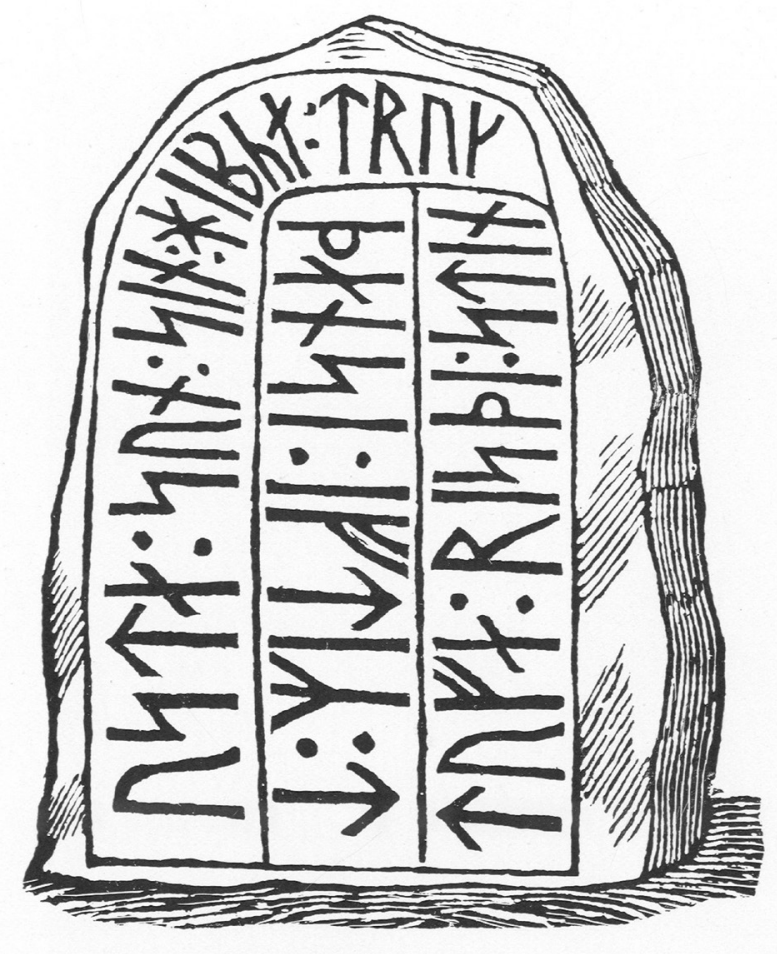

Figure 2. The Hjermind stone 2, Jutland, Denmark (after woodcut by Worm reproduced in Jacobsen and Moltke 1941, plate 214).

The oldest Christian rune stones were raised by believers, who asked God to help the souls of their deceased relatives (Herschend 1994, 101). Torun Zachrisson equals this to the requiem mass, where the souls of the dead should find the right way to the light and paradise by means of prayers of the bereaved and the help of God and God's mother (Zachrisson 1998, 148). A central source for this interpretation is found in an English collection of sermon texts by Wulfstan of York (d. 1023 AD), were the building of bridges is described as a good Christian deed that will help the soul on its difficult journey (Roesdahl 1990, 26).

\section{Separating Categories of Beings}

Whereas the bridge as a phenomenon has been studied by numerous scholars, little attention has been given to the fact that during the Viking Age, the shape of the stone and the different sides of the stone are also used to underline the junction between different categories of being, such as living and dead, and to classify the social role of the de- 
Figure 3. The Tryggevælde stone, Zealand, Denmark (after Jacobsen and Moltke 1941, plate 556-558, 560).
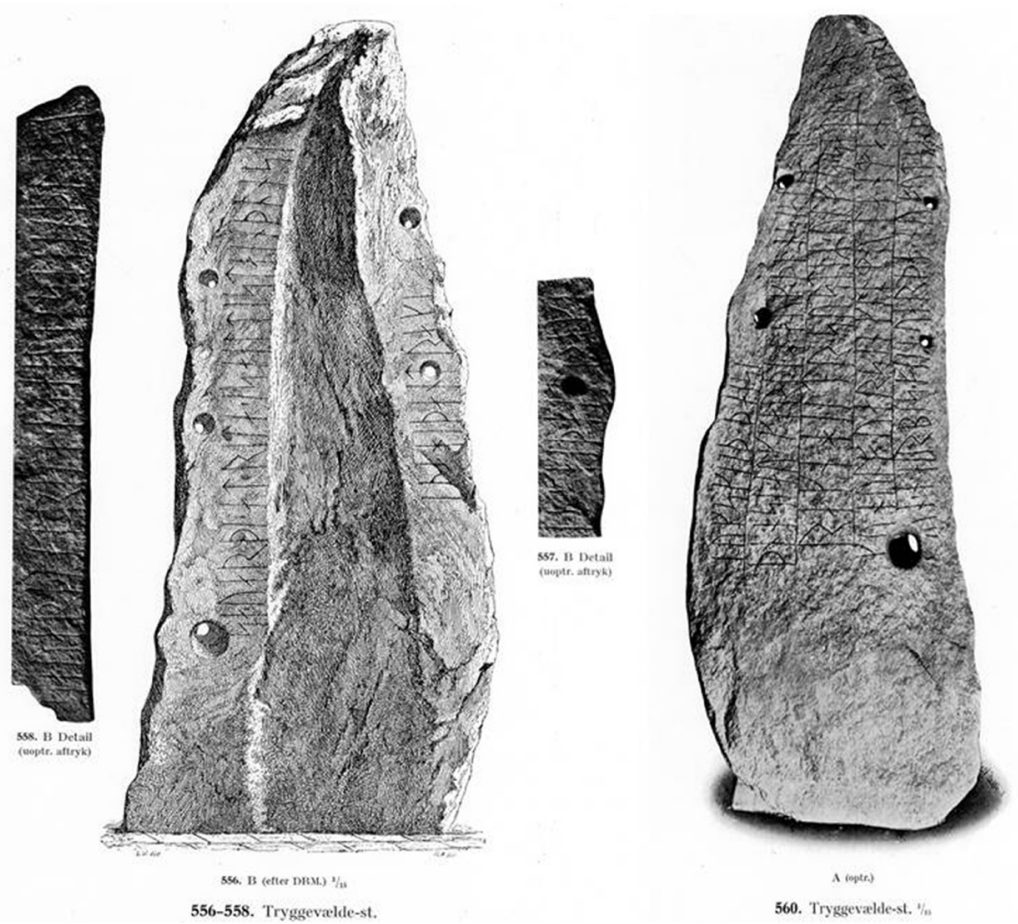

ceased. In these instances, the name of the raiser is on one side of the stone, the name of the deceased on the following side, and on the third side the inscription may include a statement; in other examples this division is made through the carving in separate bands. For instance, the different sides of the stone are used for separating the living raiser and the deceased relative on rune stones such as the Vordingborg stone (DR 221), Zealand. This stone may be of the Pre-conversion group, dating it to c. 900-970 AD, but due to the fact that the interpretation of the inscription is uncertain, the dating of the Vordingborg stone is expanded to include the $9^{\text {th }}$ century in the Danish rune database (Imer 2014, 168-171, 173; Jacobsen and Moltke $1941,208-209,1942,271-274)$. Thus, it is the materiality of the stone that is actively used to underscore this distinction. The immanent qualities of the stone, including its shape, were enhanced through the moderation and manufacturing of it in order to match the principles of categorisation conveyed in the inscription. The rune stone from Tryggevælde (DR 230) is another example of these two dispositions.

The stone has two broad sides with inscriptions and two narrow sides without. The inscription on one of the broader sides includes four bands: One mentions the raiser and her kin, one describes the deeds; raising the stone and building a mound, one mentions the deceased (her husband), and the final describes his kin and qualities. On the upside, broad side is a warning that 'he, who ailti' or remove this stone will become a 'rita's. At some point after the stone was inscribed, five holes have been drilled through the stone (Figure 3). These perforations appear to partly respect the inscription, as they only destroy small parts of six runes. The stone is of the Pre-conversion group, dating it to the period between 900 and c. 970 AD (Imer 2014; Jacobsen and Moltke 1941, 217-219, 1942, 281-286, 1022-1023). The stone demonstrates that the inscriber used the bands as a means of expressing fundamental categories in the cognitive schemes by separating persons, their affiliations, and qualities. Furthermore, the shape of the stone and the different sides of the stone were employed to underline these divisions. Like a number of Viking Age and Early Medieval rune stones, the Tryggevælde stone has been worked prior to the inscription. This means that not only was the original shape of the stone used consciously, but it was even altered in order to make it express these divides.

The utilisation of the shape of the stone and the sides of the stone for structuring the diverging categories appears on rune stones with explicit pagan inscription as well as on the early explicitly Christian rune stones, as the examples from Tryggevælde 

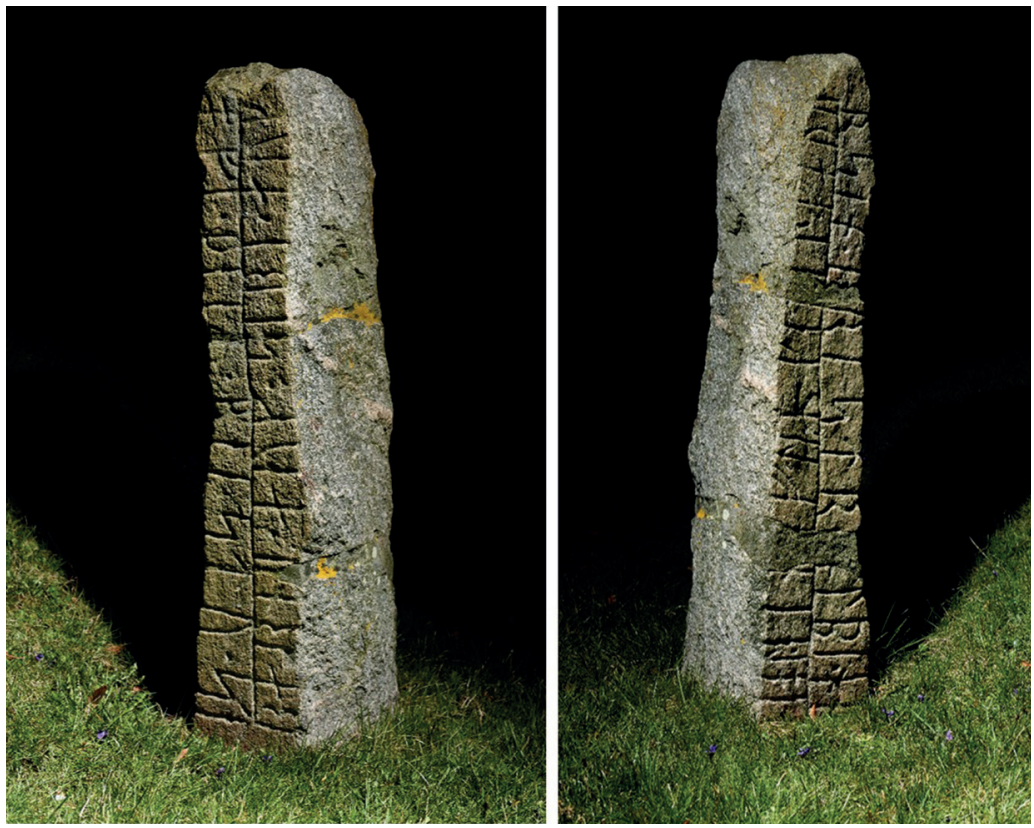

Figure 4. The Østermarie stone II, Bornholm, Denmark (photos: Roberto Fortuna, The National Museum of Denmark).

and Källstorp demonstrate. This custom continues in the Bornholm group of stones dating to 1025$1125 \mathrm{AD}$ (Imer 2014, 172-173), as seen on the Østermarie stone II (DR 391), Bornholm, where side $A$ states the name of the raisers, side $B$ mentions the deceased, their father and in addition 'Christ help his soul', thus locating the living on one side, and the deceased and Christ on the other (Figure 4).

Similarly, on Østerlarsker II (DR 398), Bornholm, which is inscribed on three sides of the stone, side A mentions the raisers and the stone, side B follows with the deceased and the relation to the raisers (their father), and finally side C pray that 'Christ and St Mikkel and St Maria help his soul'(Jacobsen and Moltke 1941, 372, 384-385, 1942, 449-451, 456-457). Thus, the disparity between different beings and qualities was expressed through spatial segregation on the rune stones. This separation in space of living, deceased, types of relation, curses (on the pagan stones) or Christ and saints (on the Christian ones) was produced with the construction and shape of the bands for the inscription, but also through the use of the materiality of the stone and alterations to the structure of the stone. Further, traces of paint, mainly red and black, on a few Swedish rune stones indicate that when rune stones were painted, the inscriptions were coloured in accordance to syntax, so that a description of the relation between the deceased and the raisers of the stone pair brøor (these brothers) were painted in one colour and the following part letu reisa (let raise) in another (Jansson 1984, 168). If we understand rune stones as repositories for collective memory, these effects caused by the divisions of being in separate bands and perhaps divided with separate colours were passed on to future generations that met, read, and engaged with the rune stone.

\section{From the Earth to the Sky}

Memory works through bodily practices like movements and gestures. Thus, specific bodily actions can recall past memories (Connerton 1989; Mauss 1973). This calls for a focus on the sensorial aspects of engaging with material culture (Hamilakis 2013). New ways of structuring the inscription on the rune stones also included new ways of reading it; a process which included an alteration in the bodily practices of reading. A small group of Post-conversion rune stones were inscribed in a manner which differed significantly from the older stones. These stones did not have any division of lines between the deceased and the bereaved, but were instead carved in the stone in one vertical band. Most of these inscriptions run from the bottom and upwards. The 196 $\mathrm{cm}$ high rune stone Århus 4 (DR67) from Jutland, Denmark, is of the Post-conversion group, dating it to the period c. 970-1025 (Imer 2014, Stoklund 1991). It is written in one band from the bottom up, stating that 'Kald raised stone this after Inge, father his' (Jacobsen and Moltke 1942, 104)(Figure 5). 
The inscription begins approximately $50 \mathrm{~cm}$ above ground, and the first letter in the name 'Inge' is located in the height of $165 \mathrm{~cm}$ above ground followed by the addition 'father his' running from 175 to $196 \mathrm{~cm}$ height. The average height of Viking Age women and men have been measured based on the skeleton remains from inhumation graves, thus most probably implicating an overrepresentation of the elite of both sexes (see Price 2008b, for a further discussion on the social groups represented in Viking Age burials). These individuals may potentially also be part of the social group which was most likely to be literate. Based on 320 individuals, the average height of women has been estimated to approximately $158 \mathrm{~cm}$, and of men, to $172 \mathrm{~cm}$ in Viking Age Denmark (Sellevold et al. 1984, 175181). The sight would be turned upwards for any inscription above respectively around 155 and 168 $\mathrm{cm}$ (as the eyes are placed some centimetres below the top of the head). Consequently, in order to read the inscription, the reader would have had to lift the sight towards the sky and turn the head slightly backwards. Similarly, Østermarie rune stone IV (DR 393) from Bornholm from the pre-Middle Ages group was inscribed with one line in a band, 'Bove let carve stone after Thykil(Jacobsen and Moltke 1941, 379, 1942, 452-453)(Figure 6). The stone is $225 \mathrm{~cm}$ high, and the name Thykil starts at approximately $168 \mathrm{~cm}$ above ground and ends at $225 \mathrm{~cm}$ above ground, thus forcing the reader to raise the head towards the sky to read the name of Thykil and thereby actively commemorating him.

On the Fjenneslev stone (DR 238) from Zealand the inscription states that 'Sasser raised the stone and made the bridge'. This stone is of the post-Conversion group, dating it to ca. 970-1020/1025 AD (Imer 2014; Stoklund 2006). It is interpreted as a Christian inscription, as a cross is placed in front of the first word, the name 'Sasser'. In contrast to the earlier inscriptions, this text is read from the top down, and not bottom up. This means that the highest word is 'Sasser'. The tradition of raising stones over oneself as opposed to raising a stone to commemorate another is rare, but does occur in a few other incidents - all Christian stones. The Fjenneslev stone is $220 \mathrm{~cm}$ high, which places the name of Sasser higher than the person reading the inscription. Again, the reader is forced to raise the

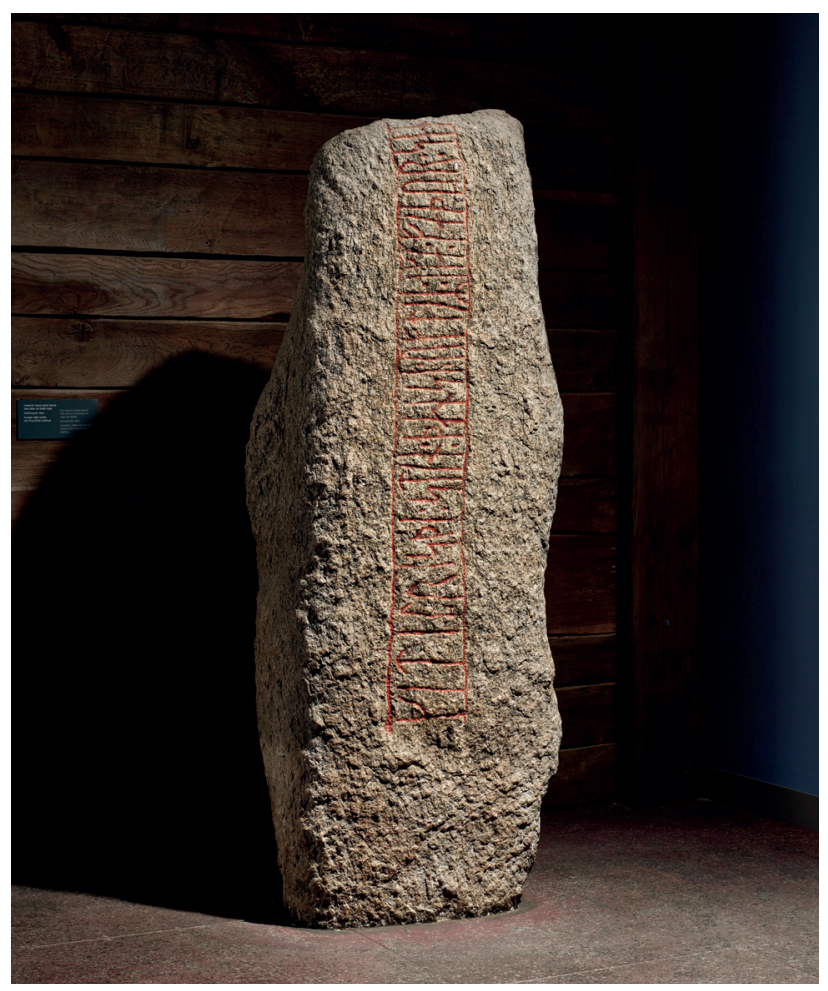

Figure 5. The Århus stone IV, Jutland, Denmark (photo: Roberto Fortuna, The National Museum of Denmark).

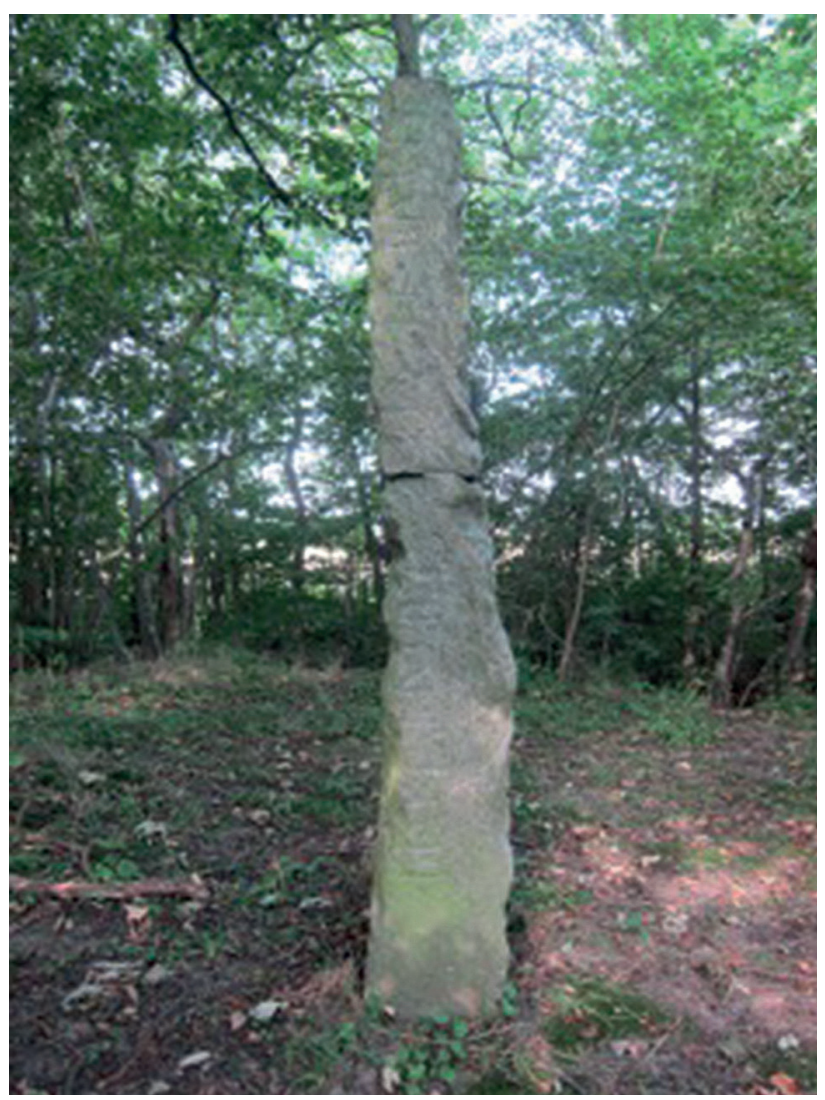

Figure 6. The Østermarie rune stone IV, Bornholm, Denmark located at a crossing point of the stream Gyldenså. By a curiosa, the author of this article is of the average height of a Viking Age woman. Thus, the photo is taken from the sight height of an average Viking woman (photo: Julie Lund). 
sight upwards (Jacobsen and Moltke 1941, 224225, 1942, 291-292). The Dynna stone (N 686) from Hadeland may be seen as another variation of this phenomenon. The stone is dated to first half of the $11^{\text {th }}$ century due to the elaborate pictures on the stone being in Ringerike style (Fuglesang 1980). The inscription states that 'Gunnvor made the bridge, Trydrik's daughter, after Astrid, her dotter. She was the most dexterous maiden in Hadeland' (Olsen 1941, 198, see also Spurkland and Van der Hoek 2005). The inscription is engraved on the narrow side of the stone. On the broad side of the stone is the image of a figure with a glory, and figures interpreted as scenes from the epiphany, including three riders under each other. Below the lowest rider is an ornament of six so-called Irish slurs, divided in two lines. The scene has been interpreted as the three wise men (Staecker 2004, 49). The image on the broad side of the stone and the text on the narrow side have generally not been linked in the interpretations. Nevertheless, it is striking that the Irish slurs figuratively form a bridge, which the lowest of the horses is crossing. The word bridge in the inscription on the narrow side is engraved exactly against the Irish slurs. In that way the Irish slurs could be seen as a bridge where the three wise men can cross, underlining the Christian meaning of the bridge (Lund 2005, 125). The stone is $282 \mathrm{~cm}$ high. The last part of the inscription from the name Astrid and the following text is so high up that any person would have to lift the sight towards the sky to read it.

This shift emerged on stones of South Scandinavian rune stones from the Post-conversion group (c. 970-1020/1025 AD) and the Bornholm group (c. 1025-1125 AD) (Imer 2014) and on the explicitly Christian early $11^{\text {th }}$ century for the rune stone from Hadeland (Fuglesang 2005; Staecker 2004). The examples of this type of inscriptions, one line in one band, are few and are unparalleled in the rune stones from previous periods. In other words, this alteration appeared concurrently with the conversion to Christianity in the area in which they were raised. Statistically, these examples do not make out a large proportion of the South Scandinavian rune stones, as only 6 stones $^{7}$ with this pattern have been identified (thus, only $2.9 \%$ of all Pre- and Post-conversion group rune stones and $2.3 \%$ of the Bornholm Group). Yet, they all appear as part of the earliest Christian inscriptions in the area in which they were raised, and thus they appear as a new scheme for the spatial structuration of the inscription. As Imer has pointed out, a number of rune stones which have hitherto been identified as Post-Jelling and thus Post-conversion cannot be differentiated from the older Jelling and Pre-Jelling stones with certainty, and must therefore be categorised more generally as part of this Pre- and Post-conversion group (Imer 2014). The number of explicitly Christian Post-conversion stones is however also very small, with only 13 stones from present-day Denmark and Scania. The group of rune stones with the band running from the earth to the sky is all but one part of this group of explicitly Christian rune stones. They also form a large proportion of the explicit Christian stones (30.8\%). Thereby, they also make out a large part of the stones that with certainty were raised Post-conversion. In addition there is the Århus stone 4 which does not have an explicit Christian inscription, but which has hitherto been interpreted as a Post-Jelling and thus potentially Post-conversion stone. The emergence of this new phenomenon of rune stones with the inscription running from the earth to the sky in one band marks an alteration of the rune stones, where the textual inscription, the size of the stone and the spatial pattern of the inscription on the surface of the stone were utilised in a new way, which compelled the reader to look towards the sky when reading the name of the deceased. They indicate a dawning perception of the otherworld as located on a vertical axis, above ground, in the sky. The concept of heaven above may thus have been expressed materially in the action of raising these stones, and incorporated bodily through the act of reading the inscription. In this sense the concept of the sky was directly linked to the bodily experience of reading and relating to the rune stone.

In spite of the introduction of this new theme, these stones are simultaneously linked to older traditions in their use of the landscape. For instance, the Dynna stone is placed in relation to burial mounds from the early and late Iron Age. Others, like the Fuglie stone 2, had a surface covered with cup marks from the Bronze Age (Imer 2016, 267 - 
Figure 7. Pre-Roman Menhirs at Louiselund, Bornholm, Denmark located $1 \mathrm{~km}$ East of the Østermarie rune stone IV (Figure 6 ) at a crossing point of the stream Gyldenså (photo: Julie Lund).

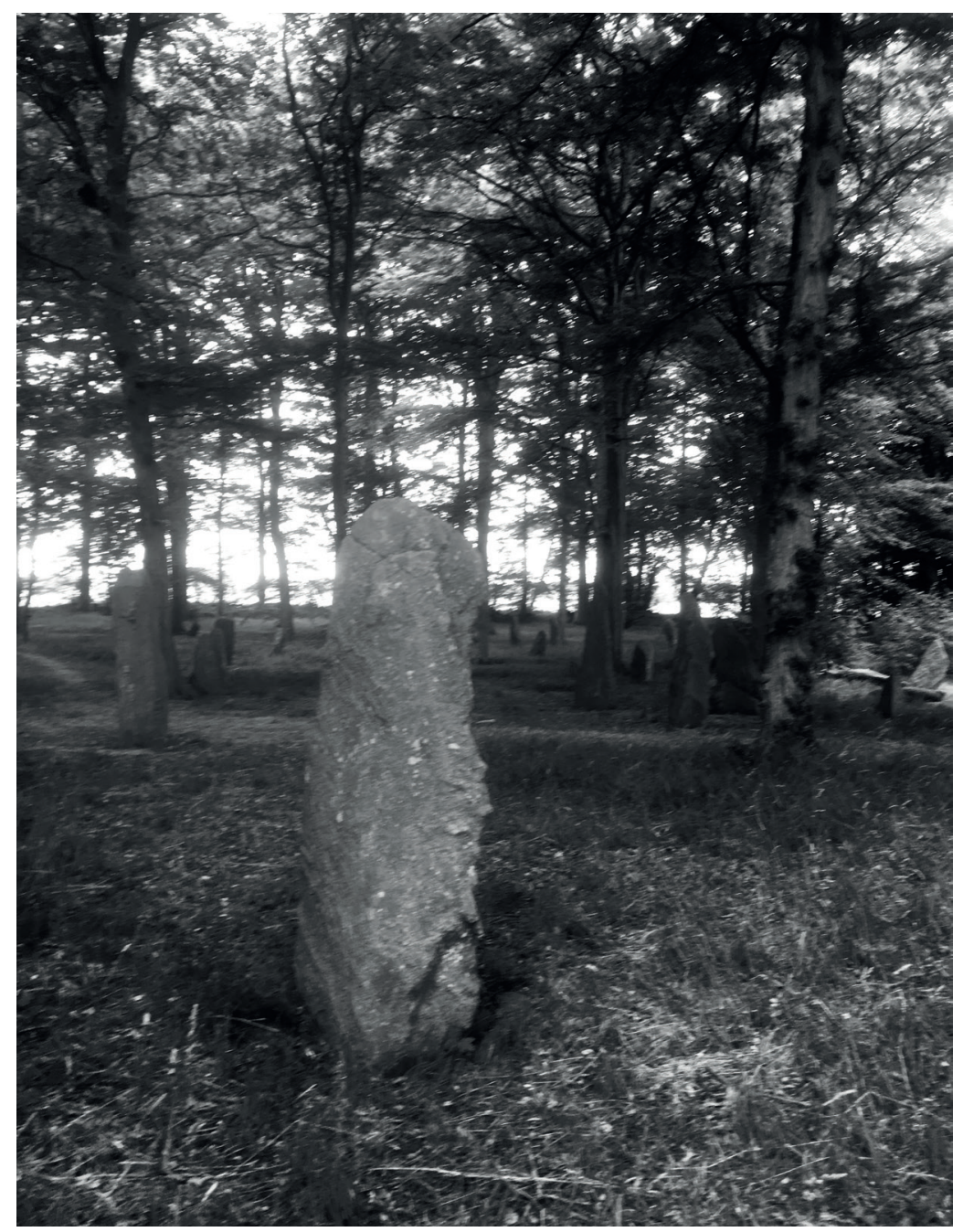

268). Furthermore, rune stones were not the first stones to be raised in the Scandinavian landscape. In the $1^{\text {st }}$ millennium $\mathrm{BC}$ in the late Bronze Age and Pre-Roman Iron Age, menhirs or bautas were raised, either in relation to cairns or cremation graves, or standing alone in the landscape. They were often located at places where they were visible from afar; at the coast, at fords, along a stream, or on a ridge (Jensen 2003). In this sense the rune stones relate to a much older commemorative tradition (Bianchi 2010, 224). In a few instances they have later been incorporated into ship settings. The location of the Late Viking Age rune stones show similar tendencies, as they tend to have been raised at burial sites, along roads, at fords and bridges, and in a few instances they were built into older ship settings (Enoksen 1999; Larsson 1990; Vestergaard 2007). They carried references to - and citations of - older monuments (see Lund and Arwill-Nordbladh 2016, with references for a further discussion of the rune stones as material citations). In many cases, menhirs are visible from the loca- tion were Viking Age rune stones were raised (Back Danielsson 2015b, 72-73; Knutzen 2005, 2007). Since Bornholm is one of the places in Scandinavia with the highest density of menhirs, the relations between menhirs and rune stones are also present in this body of material. The rune stone Østermarie IV is placed at a bridge at the stream Gyldenså. One kilometre further down this very stream, East of Østermarie stone IV, at the next crossing point lays Louiselund, which is arguably the largest Danish collection of menhirs from the Late Bronze Age and Pre-Roman Iron Age (Figure 7).

Thus, when people met and read the early Christian rune stones, this physical engagement with the stone through walking up to it, meeting it, reading it, passing it, and seeing and knowing of other raised stones in the surrounding landscape may have created links to a distant past (for a study of the physical engagement with a group of rune stones, see also Back Danielsson 2015b). Though there was no longer a collective memory 
of the people or events which had caused the raising of the menhirs a thousand years earlier, they were integrated into the early Christian landscape of commemoration. Thereby, this group of stones with the inscription running in a vertical band are part of an alteration in the way the landscape was used, conceptualised and bodily incorporated, but they are by no means examples of a complete break with the former rune stone traditions.

\section{Rune Stones as Social Relations}

The reading of the rune stones included understanding the runes in terms of literacy, but also of linking this interaction with the inscription and the stone itself with the understanding of the landscape, including concepts of where deceased beings were located in the afterlife. The reading of the stone was consequently a sensorial interaction with matter, as Hamilakis describes it, which activated memory (Hamilakis 2013, 118-124). Thus, as the rune stones commemorated a deceased, with whom the raiser of the stone was closely related through kinship or other social bonds, new Christian ideas of the landscape and the spatially aspects of the afterlife was physically inscribed into the readers of the rune stone inscriptions.

Above, three phenomena have been explored. Firstly, the rune stones at bridges use the surface and shape of the stone to refer to the use of the landscape. Secondly, the surface and shape of the stones are used to separate diverging states of being and qualities. Lastly, the inscriptions running from the surface and upward are active components in incorporating new concepts of otherworlds, as heaven is now placed in the sky. The last phenomenon is not a dominant feature in the body of material examined here, but it is noticeable that it emerges on some of the earliest explicitly Christian rune stones in South Scandinavia. If we approach these inscriptions on the rune stones are materialisations of social relations, this interplay with the shape of the stones and its relations to the landscape in which it was situated in (and sometimes moved into) demonstrates that these were not mere texts, nor simply manifestations of power or claims of land. Back Danielsson com- pares the size and stature of the rune stone to that of a person. She argues that the stones from the Mälar region may have been perceived as possessing agency and personhood based on inscription using the world 'me' and the use of the verb fyrpi, meaning brought, referring to the rune stone, as this verb is otherwise only used for actions done by human beings (Back Danielsson 2015a, 166). There is no such clear indication that the rune stones of the Pre- and Post-conversion group and the Bornholm group presented in this paper were also perceived as possessing personhood (see Lund 2017, for a discussion of personhood in Viking ontology); but if we cannot determine whether they were stone-persons or not, we can conclude that they were stone-bodies in the sense that their scale and size forced people to relate to and engage with them due to their placement in the landscape. The South Scandinavian rune stones of the Pre- and Post-conversion group and the Bornholm group were, in general, larger than human. They were located in an open agricultural landscape without mountains and with few visible rocks. The massive Fjenneslev stone, to take one example, is $220 \mathrm{~cm}$ high and $126 \mathrm{~cm}$ wide, heavier and larger than any human person, carved with runes. It had effect and affect on any person, literate or illiterate, that passed the stone (Figure 8).

Thus, the size and weight of these stones also caused and causes effects on the human body that meet and read the stone, be it by recalling the use of the bridge, by raising the sight towards the sky or by walking around the stone in order to identify the different beings separated by the surface of the stone and divided in different carved bands of inscription. The stone not only commemorated the deceased, but it materialised the social relation between the commemorated and the raiser of the stone, leaving a lasting impact on the landscape. Long after the body of the deceased has decayed the memory of the relationship between the deceased and the raiser of the stone is still preserved today as an enduring, material stone body. 


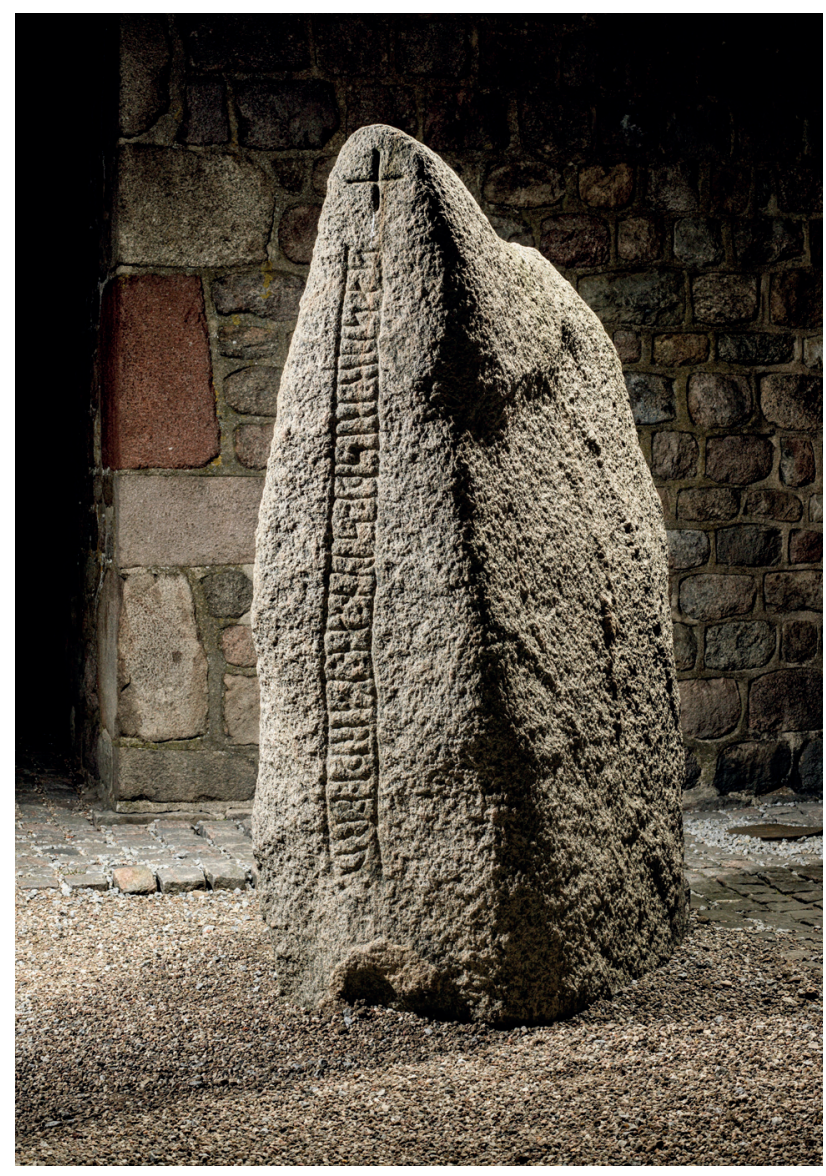

Figure 8. The Fjenneslev stone, Zealand, Denmark (Photo: Roberto Fortuna, The National Museum of Denmark).

\section{Changing Efficacies of Commemoration}

Torun Zachrisson points out that the Eddic poem Rigspula draws a connection between owning odal land and runic knowledge (Zachrisson 1994, 221). The dating of the poem Rigspula has been debated intensively, placing it in the $8^{\text {th }}-14^{\text {th }}$ century. The archaeological material described in the poem does, however, indicate that it may have existed in an oral form in the $9^{\text {th }}$ century (Lund 2009, 1820). No doubt the acts of raising rune stones were related to rights to land, ownership, and heritage. The purpose of commemoration appears to have changed from late pagan to the early Christian period. The inscriptions from the Viking Age indicate that they were raised in order to honour the deceased and to underline the link between the deceased and the raiser of the stone. This link, and thus the stone itself, may have been operational in claims of lineage and thus rights to ownership of land. In the early Christian period, emphasise is now also put on the relationship between the raiser and the deceased, including the deceased's presence in heaven above. The alteration expresses the change of religion from paganism to Christianity. The purpose of creating a place for commemoration also changed from the Viking Age to the early Christian stones, from glorifying a deceased and thereby also the family and kin to using the inscriptions to request prayers for the soul of the deceased.

The act of raising rune stones was a means of creating or transforming the place, providing it with references to specific families, genealogies and norms. In particularly the Post-conversion group of rune inscriptions from c.970-1020/1025 AD (Imer 2014) referred to defined groups of titles, such as dreng or fellow, thereby accentuating a particular set of relations. The production of the rune stone included a significant alteration of the place, making it into a distinct type of place for commemoration, the biography of the deceased and the relation between the commemorated and the stone raiser were inscribed into the landscape, and more pertinently, into the place. Raising it was part of place-making. Material culture (including human bodies and bodies of stone) played an active part in the conversion (Shaw 2013). The process of conversion included a significant alteration of ideas of the body, from extremely diverting burial practices in Viking Age Scandinavia, including fragmentation and sometimes cremation of bodies and grave goods, towards the standardised Christian inhumation grave without grave goods of the $12^{\text {th }}$ century (Lund 2013). In between is the $11^{\text {th }}$ century, a period where whole bodies were followed in the grave by lesser amounts of grave goods, but in all cases of whole objects, pointing towards a parallelism between the handling of bodies and objects (Lund 2013, 53-57). This transformation during the $11^{\text {th }}$ century should not be reduced to a hybrid state, with combinations of the old and the new. Rather than understanding this as an example of syncretism, and as symbols of something else, it should be seen as practices. As the conversion in Scandinavia was incorporated through new rites, including burials, it gave rise to new conceptions of the integrity of the whole body and of whole objects (Lund 2013, 56-57). At the same time, a 
group of rune stones were inscribed in a new manner, with a single line from the bottom up, forcing the sight towards the sky as part of reading and remembering the inscription, thus compelling the body of the reader or observer of the stone to react to it in a new way. In the Christian understanding of the landscape, the physical location of the deceased was thus compelled onto the body of the reader of the inscription. This process was further underlined by using large stones, larger than human, as rune stone bodies.

\section{Notes}

1 The Sö numbers refer to the registration of the rune stones from Södermansland, Sweden in E. Brate and E. Wessén 1924-1936 Södermanlands runinskrifter. Sveriges runinskrifter, volume 3. Stockholm: Wahlström \& Widstrand.

2 The rune stones in Gottorp County in Schleswig, Ger- many are included in the volumes and registers of Danish rune stones and have therefore also been included in this article.

3 For instance in Hesselbjerg at Odder, Gammelby at Esbjerg, Volstrup in Vendsyssel and Gl. Lejre at Roskilde in Denmark fall within this pattern (Adamsen 2004).

4 There is no certain translation of 'ailti', but the context indicates that it is some kind of destruction.

5 The translation of the word is uncertain, but the context indicates that it is not something positive.

6 The $\mathrm{N}$ number refers to the registration of the rune stones in the Rune Archive in Museum of Cultural History, University of Oslo and in M. Olsen Norges innskrifter med de yngre runer. Norsk historisk kjeldeskrift-institutt, Oslo. Olsen, Magnus (1941). Norges innskrifter med de yngre runer / utgitt for Kjeldeskriftfondet, Oslo, Norsk historisk kjeldeskrift-institutt.

7 The Århus stone 4 (DR67), the Fjenneslev stone (DR 238), the Fuglie-stenen 2, the Norra Nöbbelöv stone (DR316), and the two inscriptions on the Lund stone 1 (DR 214) are all from the Post-conversion group and are explicitly Christian rune stones, as is the Østermarie stone IV from the Bornholm group.

\section{Bibliography}

Adamsen, C., 2004. På den anden side. Skalk (5), 20-28.

Andrén, A., 2000. Re-reading Embodied Texts - an Interpretation of Rune-stones. Current Swedish Archaeology, 8, 7-32.

Andrén, A., 2013. Places, Monuments, and Objects: The Past in Ancient Scandinavia. Scandinavian Studies, 85(3), 267-281. https://doi.org/10.1353/scd.2013.0034

Artelius, T., 2004. Minnesmakarnas verkstad. Om vikingatida bruk av äldre gravar och begravningsplatser. In: Å. Berggren, S. Arvidsson and A.-M. Hållans, eds. Minne och myt-konsten att skapa det förflutna. Lund: Nordic Academic Press, 99-120.

Arwill-Nordbladh, E., 2008. Aska och Rök - om minne och materiell kultur i nordisk vikingatid. In: B. Pettersson and P. Skoglund, eds. Arkeologi og identitet. Lund: Institutionen för arkeologi och antikens historie, 169-188.

Assmann, J., 1995. Collective Memory and Cultural Identity. New German Critique, 65, 125-133. https://doi.org/10.2307/488538

Back Danielsson, I.-M., 2015a. The Social Qualia of Kuml. Current Swedish Archaeology, 23, 157-178.

Back Danielsson, I.-M., 2015b. Walking down memory lane. The mnemonic agency of Late Iron Age Scandinavian Rune Stones. In: M. Gondek, J. Kirton and H. Williams, eds. Memories in the Making. 
The Materialities, Biographies and Landscapes of Early Medieval Stone Monuments. New York: Boydell Press.

Bianchi, M., 2010. Runor som resurs. Vikingatida skriftkultur i Uppland och Södermanland. Uppsala: Institutionen för nordiska språk, Uppsala universitet.

Bradley, R., 1993. Altering the earth. The origins of monuments in Britain and Continental Europe: the Rhind lectures 1991-92. Edinburgh: Society of Antiquaries of Scotland.

Brate, E. and Wessén, E., 1924-36. Södermanlands runinskrifter. Stockholm: Wahlström \& Widstrand.

Brink, S., 2007. Skiringsal, Kaupang, Tjølling - the Toponymic Evidence. In: D. Skre, ed. Kaupang in Skiringssal. Højbjerg: Aarhus University Press.

Brink, S., 2008. Landskap och plats som mentala konstruktioner. In: K. Chilidis, J. Lund and C. Prescott, eds. Facets of Archeology. Essays in Honour of Lotte Hedeager on her 60 ${ }^{\text {th }}$ Birthday. Oslo: Unipub, 109-120.

Connerton, P., 1989. How societies remember. Cambridge: Cambridge University Press.

Enoksen, L.M., 1999. Skånska runstenar. Lund: Historiska media.

Fuglesang, S.H., 1980. Some aspects of the Ringerike style a phase of $11^{\text {th }}$ century Scandinavian art. Odense: Odense University Press.

Fuglesang, S.H., 1981. Vikingetidens kunst. In: K. Berg, ed. Norges kunsthistorie. 1. Fra Oseberg til Borgrund. Oslo: Gyldendal.

Fuglesang, S.H., 2005. Runesteinenes ikonografi. hikuin, 32, 75-94.

Gadamer, H.-G., 2001 [1960]. Opphøyelsen av forståelsens historisitet til hermeneutisk prinsipp. In: S. Lægreid and T. Skorgen, eds. Hermeneutisk lesebok. Oslo: Spartacus.

Gilchrist, R., 2013. The materiality of medieval heirlooms: From biographical to sacred objects. In: H.P. Hahn and H. Weiss, eds. Mobility, Meaning and Tranformations of Things. Shifting contexts of material culture through time and space. Oxford/Oakville: Oxbow Books, 170-183.

Gosden, C., 2005. What Do Objects Want? Journal of Archaeological Method and Theory, 12(3), 193-211. https://doi.org/10.1007/s10816-005-6928-x

Gräslund, A.-S., 2002. Runstensstudier. Uppsala: Institutionen för arkeologi och antik historia, Uppsala Universitet.

Gräslund, A.-S., 2003. The Role of Scandinavian Women in Christianisation: The Neglected Evidence. In: M. Carver, ed. The Cross goes North: Processes of Conversion in Northern Europe AD 300-1300, Woodbridge: York Medieval Press, 483-496.

Gräslund, A.-S. and Lager, L., 2008. Runestones and the Christian missions. In: S. Brink and N.S. Price, eds. The Viking World. London/New York: Routledge, 629-638. 
Halbwachs, M., 1992. On collective memory. Chicago, Ill: University of Chicago Press.

Hamilakis, Y., 2013. Archaeology and the senses: human experience, memory and affect. New York: Cambridge University Press.

Harris, O., 2010. Emotional and mnemonic geographies at Hambledon Hill: texturing Neolithic places with bodies and bones. Cambridge Archaeological Journal, 20 (3), 357-371.

https://doi.org/10.1017/s0959774310000466

Harris, O., 2016. Affective architecture in Ardnamurchan: asseblages at three scales. In: T. Flohr Sørensen and M. Bille, eds. Elements of Architecture. Assembling archaeology, atmosphere and the performance of building spaces. London/New York: Routledge, 195-212.

Hedeager, L., 2002. Scandinavian 'Central Places' in a Cosmological Setting. In: L. Larsson and B. Hårdh, eds. Central places in the Migration and Merovingian periods: papers from the $52^{\text {nd }}$ Sachsensymposium, Lund, August 2001. Stockholm: Almqvist \& Wiksell, 3-18.

Hedeager, L., 2003. Kognitiv topografi: Ædelmetalldepoter i landskapet. In: P. Rolfsen and F.-A. Stylegar, eds. Snartemofunnene i nytt lys. Oslo: Universitetets Kulturhistoriske Museer, 147-166.

Herschend, F., 1994. The Recasting of a Symbolic Value - Three Case Studies on Rune Stones. Uppsala: Societas Archaeologica Uppsaliensis.

Hållans Stenholm, A.-M., 2006. Past Memories: Spatial Returning as Ritualized Remembrance. In: A. Andrén, K. Jennbert and C. Raudvere, eds. Old Norse Religion in Long-Term Perspectives. Origins, Changes and Interactions. Lund: Nordic Academic Press, 341-345.

Imer, L., 2014. The Danish Runestones - When and Where? Danish Journal of Archaeology, 3(2), 164174. https://doi.org/10.1080/21662282.2015.1104905

Imer, L., 2016. Danmarks Runesten. En fortalling. Nationalmuseet, København: Gyldendal.

Ingold, T., 1993. The Temporality of the Landscape. World Archaeology, 25(2, Conceptions of Time and Ancient Society), 152-174.

Jacobsen, L. and Moltke, E., 1941. Danmarks runeindskrifter. Atlas. København: Ejnar Munksgaards Forlag.

Jacobsen, L. and Moltke, E., 1942. Danmarks runeindskrifter. Text. København: Ejnar Munksgaards Forlag.

Jansson, S.B.F., 1984. Runinskrifter i Sverige. Stockholm: AWE/Gebers.

Jensen, J., 2003. Aldre Jernalder 500 f.Kr. -400 e.Kr. København: Nordisk Forlag A/S.

Jesch, J., 1991. Women in the Viking Age. Suffolk: Boydell press.

Jones, A., 1998. Where Eagles Dare. Landscape, Animals and the Neolithic of Orkney. Journal of material culture, 3(3), 301-324. https://doi.org/10.1177/135918359800300303 
Jones, A. 2007. Memory and Material Culture. Cambridge, Cambridge University Press.

Klos, L. 2009. Runensteine in Schweden. Studien zu Aufstellungsort und Funktion. New York: Walter de Gruyter.

Knutzen, T., 2005. Kristen innflytelse i hedensk tid?: en analyse med utgangspunkt i graver fra yngre jernalder i Hordaland. In: Terje Østigaard, ed. Lik og ulik. Tilnarminger til variasjon i gravskikk. Bergen: Arkeologisk institutt, Universitetet i Bergen,95-112

Knutzen, T., 2007. Bautasteiner på Sunnmøre: en analyse av steinenes betydning og funksjon $i$ tid og rom. UBAS Universitetet i Bergen Arkeologiske Skrifter, hovedfag/master 2. Bergen: Arkeologisk Institutt, Universitetet i Bergen, 273-407.

Kohring, S., 2014. Materiality, Technology, and Constructing Social Knowledge through Bodily Representation: A View from Prehistoric Guernsey, Channel Islands. European Journal of Archaeology, 17(2), 248-263. https://doi.org/10.1179/1461957114y.0000000055

Krogh, K.J., 1982. The Royal Viking-Age Monuments at Jelling in the Light of Recent Archaeological Excavations. Acta Archaeologica, 53, 183-216.

Lager, L., 2003. Runestones and the conversion of Sweden. In: M. Carver, ed. The Cross goes North, AD 300-1300. Woodbridge: York Medieval Press, 497-508.

Larsson, M.G. 1990. Runstenar och utlandsfärder: aspekter på det senvikingatida sambället med utgångspunkt $i$ de fasta fornlämningarna. Avhandling (doktorgrad), Lunds universitet, 1990. Stockholm: Almqvist \& Wiksell International.

Ljung, C., 2016. Under runristad häll, Tidigkristna gravmonument i 1000-talets Sverige. Stockholm Studies in Archaeology, 67,1. Stockholm: Explicare.

Lund, J., 2005. Thresholds and Passages: The Meanings of Bridges and Crossings in the Viking Age and Early Middle Ages. Viking and Medieval Scandinavia, 1, 109-137.

https://doi.org/10.1484/j.vms.2.3017467

Lund, J., 2009. Åsted og vadested. Deponeringer, genstandsbiografier og rumlig strukturering som kilde til vikingetidens kognitive landskaber. Oslo: Unipub.

Lund, J., 2013. Fragments of a conversion: handling bodies and objects in pagan and Christian Scandinavia AD 800-1100. World Archaeology, 45(1), 46-63.

https://doi.org/10.1080/00438243.2012.759511

Lund, J., 2017. Connectedness with Things. Animated objects of Viking Age Scandinavia and Early Medieval Europe. Archaeological dialogues, 24(1), 89-108. https://doi.org/10.1017/s1380203817000058

Lund, J. and Arwill-Nordbladh, E., 2016. Divergent ways of relating to the past in the Viking Age. European Journal of Archaeology, 19(3), 415-438. https://doi.org/10.1080/14619571.2016.1193979

Malafouris, L., 2013. How Things Shape the Mind: a Theory of Material Engagement. Cambridge, Mass.: MIT Press. https://doi.org/10.7551/mitpress/9476.001.0001 
Mauss, M., 1973. Techniques of the body. Economy and Society, 2(1), 70-88.

Merleau-Ponty, M., 1994. Kroppens fenomenologi. Oslo: Pax Forlag A/S.

Moser, M.,-B. and Moser, E., 1998. Distributed Encoding and Retrieval of Spatial Memory in the Hippecampus. The Journal of Neuroscience, 18(18), 7535-7542.

https://doi.org/10.1523/jneurosci.18-18-07535.1998

Moser, E., 2005. Interview med Professor Edvard Moser, Centre for the Biology of Memory, Norwegian University of Science and Technology. Trykt på hjemmesiden www.forskning.no, publiceret 2. juli 2005, (http://www.forskning.no/Artikler/2005/juli/1121938991.86).

Olick, J.K., 1999. Collective Memory: The Two Cultures. Sociological Theory, 17(3), 333-348. https://doi.org/10.1111/0735-2751.00083

Olsen, M., 1941. Norges innskrifter med de yngre runer / utgitt for Kjeldeskriftfondet. Oslo: Norsk historisk kjeldeskrift-institutt.

Pedersen, A., 2006. Ancient mounds for new graves. An aspect of Viking Age burial customs in southern Scandinavia. In: A. Andrén, K. Jennbert and C. Raudvere, eds. Old Norse religion in long-term perspectives. Origins, changes, and interactions. Lund: Nordic Academic Press, 346-353.

Pétursdóttir, P., 2012. Concrete matters: Ruins of modernity and the things called heritage. Journal of Social Archaeology, 13(1), 31-53. https://doi.org/10.1177/1469605312456342

Price, N.S., 2008a. Bodylore and the Archaeology of Embedded Religion: Dramatic Licence in the Funerals of the Vikings. In: K. Hays-Gilpin and D.S. Whitley, eds. Belief in the Past. Theoretical Approaches to the Archaeology of Religion. Walnut Creek, California: Left Coast Press, 143-165.

Price, N.S., 2008b. Dying and the dead. In: S. Brink and N.S. Price, eds. The Viking World. London/New York: Routledge, 257-273.

Price, N.S., 2014. Nine paces from Hel: time and motion in Old Norse ritual performance. World Archaeology, 46(2), 178-191. https://doi.org/10.1080/00438243.2014.883938

Randsborg, K., 1980. The Viking Age in Denmark: the formation of a state. London: Duckworth.

Robb, J.E., 2009. People of Stone: Stelae, Personhood, and Society in Prehistoric Europe. Journal of Archaeological Method and Theory, 16, 162-183. https://doi.org/10.1007/s10816-009-9066-z

Sawyer, B., 1988. Property and Inheritance in Viking Scandinavia: the Runic Evidence. Alingsås: Viktoria bokförlag.

Sawyer, B., 2000. The Viking-Age Rune Stones: Custom and Commemoration in Early Medieval Scandinavia. Oxford: Oxford University Press.

Sawyer, B., 2008. Det vikingatida runstensresandet i Skandinavien. Scandia: Tidskrift for historisk forskning, 55(2), 185-202. 
Sawyer, B., Sawyer, P.H. and Wood, I., eds., 1987. The Christianization of Scandinavia. Alingsås, Viktoria.

Sellevold, B.J., Lund Hansen, U. and Balslev Jørgensen, J., 1984. Iron Age man in Denmark. København: Det Kongelige Nordiske Oldskriftselskab.

Shaw, J., 2013. Archaeology of religious change: introduction. World Archaeology, 45(1), 1-11.

Smestad, I., 1988. Etableringen av et organiseret veihold i Midt-Norge i tidlig historisk tid. Oslo: Universitetets oldsaksamling.

Spurkland, T. and Van der Hoek, B., 2005. Norwegian runes and runic inscriptions. Woodbridge: Boydell Press.

Staecker, J., 2004. Hjälter, kungar och gudar. In: Å. Berggren, S. Arvidsson and A.-M. Hållans, eds. Minne och myt. Kunsten at skapa det förflutna. Lund: Nordic Academic Press, 39-80.

Steinsland, G., 2005. Norrøn religion. Myter, riter og samfunn. Oslo: Pax.

Steinsland, G., 2014. En kvinne velger gudbilde. In: N.L. Coleman and N. Løkka, eds. Kvinner i vikingtid. Vikingatidens kvinnor. Oslo: Spartacus, 149-165.

Stoklund, M., 1991. Runesten, kronologi og samfundsrekonstruktion. In: M. Iversen, ed. Mammen. Grav, kunst og samfund i vikingetiden. Aarhus: Aarhus Universitetsforlag, 285-298.

Stoklund, M., 2006. Chronology and Typology of the Danish Runic Inscriptions. In: M. Stoklund, M.L. Nielsen, B. Holmberg and G. Fellows-Jensen, eds. Runes and their Secrets. Copenhagen: Museum Tusculanum Press, 355-383.

Strömbäck, D., 1970. The Epiphany in runic art: the Dynna and Sika stones: the Dorothea Coke memorial lecture in northern studies delivered at University Collage, London, 22 May 1969. London: H.K. Lewis.

Sundqvist, O., 2008. Cult leaders, rulers and religion. In: S. Brink and N.S. Price, eds. The Viking World. London and New York: Routledge, 223-226.

Tarlow, S., 2012. The Archaeology of Emotion and Affect. Annual Review of Anthropology, 41, 169185.

Thomas, J., 1996. Time, culture and identity: an interpretive archaeology. London: Routledge.

Thörn, R., 2004. Med Turid i centrum - några tankar om Eik i Sokndal kommun, Rogalands fylke, Norge. In: L. Melheim, L. Hedeager and K. Oma, eds. Mellom himmel og jord: Foredrag fra et seminar om religionsarkeologi. Isegran 31. januar - 2. februar 2002. Oslo: Institutt for arkeologi, kunsthistorie og konservering, Universitetet i Oslo, 240-261.

van Dyke, R.M. and Alcock, S.E., eds., 2003. Archaeologies of Memory. Oxford: Blackwell. 
Vestergaard, F., 2007. Monumentale skibssætninger i Danmark og Skåne. Kuml. Årbog for Jysk Arkaologisk Selskab, 145-190.

Williams, H., 1998. Monuments and the past in early Anglo-Saxon England. World Archaeology, 30(1: The Past in the Past: The Reuse of Monuments), 90-108.

https://doi.org/10.1080/00438243.1998.9980399

Williams, H., 2016. Viking Mortuary Citations. European Journal of Archaeology, 19(Issue 3: Special Issue: Mortuary Citations: Death and Memory in the Viking World), 400-414.

https://doi.org/10.1080/14619571.2016.1186882

Zachrisson, T., 1994. The Odal and Its Manifestation in the Landscape. Current Swedish Archaeology, 2, 219-238.

Zachrisson, T., 1998. Gård, gräns, gravfält. Sammanhang kring ädelmetalldepåer från vikingatid och tidigmedeltid i Uppland och Gästrikland. Stockholm: Stockholm University.

Øeby-Nielsen, G., 2005. De danske runestens oprindelige plads, Kuml. Årbog for Jysk Arkøologisk Selskab, 121-144. 